\title{
The Importance of Consultation Neurology: A Patient with Anti- Glutamic Acid Decarboxylase Antibody-Associated Cerebellar Ataxia Recognized in the Psychiatry Inpatient Clinic \\ Konsültasyon Nörolojisinin Önemi: Psikiyatri Servisinde Tanınan Anti-Glutamik Asit Dekarboksilaz Antikor İlişkili Serebellar Ataksi Hastası
}

Keywords: Glutamic acid decarboxylase antibodies, stiff person syndrome, intravenous immunoglobulin, autoimmunity

Anahtar Kelimeler: Glutamik asit dekarboksilaz antikorları, katı kişi sendromu, intravenöz immünoglobulin, otoimmünite

\section{Dear Editor,}

Neurologic processes associated with anti-glutamic acid decarboxylase antibodies (anti-GAD) are rare and difficult to diagnose. This disease group may be associated with other autoimmune diseases such as insulin-dependent diabetes mellitus (DM) and includes 'stiff person syndrome' (SPS), cerebellar ataxia, gluten ataxia, progressive encephalomyelitis with rigiditymyoclonus, refractory epilepsy-limbic encephalitis, and palatal myoclonus subheadings (1).

A woman aged 25 years was evaluated during a consultation while she was hospitalized at the psychiatry clinic. Following an emotional trauma one week before, she reported anorexia, nauseavomiting, dizziness, double vision, speech and gait disturbance that were added within days. The patient, who was unable to sit without support and kept her eyes closed, had dysarthria, chaotic eye movements, fixation difficulty, and distinct truncal ataxia. Complete blood count, blood biochemistry, thyroid function tests, and beta-human chorionic gonadotropin were within normal limits. Thiamine replacement treatment was initiated, and there were no abnormalities in electroencephalography and neuroimaging studies (brain computed tomography, unenhanced and enhanced brain magnetic resonance (MR) imaging, extracranial and intracranial MR angiography). A cerebrospinal fluid (CSF) investigation revealed 35 leukocytes $/ \mathrm{mm}^{3}$, no atypical cells, normal biochemistry, an immunoglobulin (Ig) G index of 0.47 , and positive oligoclonal bands (OCB). Antiviral therapy was initiated due to CSF pleocytosis. The patient's serum immunoelectrophoresis was normal, and anti-thyroperoxidase, anti-thyroglobulin antibodies, vasculitic and infectious markers, malignancy screening and paraneoplastic antibodies (anti-Hu, anti-Yo, anti-Ri, anti-amphiphysin, anti-Tr, anti-parietal cell antibodies-2, anti-Ma, anti-CV2.1, anti-ANNA-3) were negative.

Electromyography of the patient showed increased input activity, consecutive positive spike series, fibrillation potentials and rare neuromyotonia-like discharges. With these findings interpreted in favor of "membrane hyperexcitability", intravenous Ig (IVIG) therapy was initiated with a diagnosis of "nonneoplastic immune-mediated cerebellar ataxia" due to non-clinical improvement. The serum anti-GAD antibody level was found high (54.2 IU/mL, $\mathrm{N}<10 \mathrm{IU} / \mathrm{mL}$, enzyme immunoassay) on day 6. serum anti-gliadin and anti-tissue transaminase antibodies were negative. The patient benefited from IVIG treatment and was able to walk without support at the end of the first week.

Antibodies against GAD were first described against major antigen of islet cells in patients with type 1 DM. Today, antiGAD antibody positivity is close to $80 \%$ in patients with type $1 \mathrm{DM}$ (2). The detection of anti-GAD antibodies in neurologic diseases in the absence of type 1 DM suggests that this antibody can be used as a marker in some neurologic diseases. Anti-GAD

Address for Correspondence/Yazışma Adresi: Zeynep Ezgi Balçık MD, Bakirkoy Prof. Dr. Mazhar Osman Mental Health and Neurological Disorders Training and Research Hospital, Clinic of Neurology, Istanbul, Turkey

Phone: +90 5054562952 E-mail: zeynepezgi33@hotmail.com ORCID ID: orcid.org/0000-0002-2882-7646

Received/Geliş Tarihi: 09.01.2017 Accepted/Kabul Tarihi: 21.03.2017

${ }^{\circ}$ Copyright 2017 by Turkish Neurological Society

Turkish Journal of Neurology published by Galenos Publishing House. 
antibody levels were detected at higher titers in neurologic disorders and intrathecal synthesis of this antibody was reported only in neurologic diseases. Among the diseases associated with anti-GAD antibodies, the best-known is SPS. Anti-GAD antibody is positive in $60-80 \%$ of patients with SPS. Dalakas (3) reported that anti-GAD antibody-positivity in 40 patients with SPS was accompanied by epilepsy in $8 \%$, and cerebellar ataxia in $10 \%$. This suggests that the autoimmune phenomenon of rigidity and spasms overlaps with certain forms of cerebellar ataxia and epilepsy. The presence of anti-GAD antibody positivity without SPS features in these patients indicates that anti-GAD antibodies are not specific for SPS. The detection of anti-GAD antibodies in patients with thymoma, pulmonary and breast cancer with neurologic complications in subsequent years implies paraneoplastic processes.

The prevalence of immune-mediated cerebellar ataxias has been reported as 32\% (27\% gluten ataxia, 3\% paraneoplastic cerebellar degeneration, $3 \%$ anti-GAD antibody-associated cerebellar ataxia) among sporadic ataxias (4). These data suggest that immunemediated cerebellar ataxia has a higher incidence among sporadic cerebellar ataxias than predicted.

In a series of 400 patients with ataxia, Hadjivassiliou et al. (4) reported that $20 \%$ of patients had family histories and $80 \%$ were sporadic. Two percent of 320 sporadic patients were associated with anti-GAD antibody.

Anti-GAD antibody-associated (non-neoplastic) cerebellar ataxia, which is rarely seen among immune-mediated cerebellar ataxias, arises with cerebellar syndrome symptoms. Subacute, slow and progressive courses have been defined. Although the clinical features usually become permanent within months in this disease, chronic cases have also been reported. Cerebellar atrophy can be seen in $50 \%$ of MR imaging. Mild pleocytosis and OCB positivity in CSF support the diagnosis. The diagnosis is made with clinicallysupported high serum and CSF anti-GAD antibody titers.

Treatment is based on the removal of immune triggers and immunotherapy, as described in other immune-mediated cerebellar ataxia syndromes. IV methylprednisolone, IVIG, rituximab, oral prednisolone, and combinations of these medications are used for treatment (3). Mitoma et al. (5) compared treatment responses of patients with subacute and chronic-type anti-GAD antibodyassociated cerebellar ataxia, and reported that $67 \%$ of patients with subacute-type and $42 \%$ of patients with chronic-type responded well to immunotherapy in the first three months of their symptoms.

In conclusion, "immune"-mediated ataxias are rare in the sporadic ataxia group and "anti-GAD antibody-associated cerebellar ataxia" has the lowest prevalence in this group. Early and accurate diagnosis is possible with awareness and a meticulous approach to the patient.

\section{Ethics}

Informed Consent: Consent form was filled out by all participants.

Peer-review: Internally peer-reviewed.

\section{Authorship Contributions}

Surgical and Medical Practices: Z.E.B., S.A.B., E.S., B.G., D.A., Concept: Z.E.B., S.A.B., E.S., B.G., D.A., Design: Z.E.B., S.A.B., D.A., Data Collection or Processing: Z.E.B., S.A.B., E.S., B.G., D.A., Analysis or Interpretation: Z.E.B., S.A.B., E.S., B.G., D.A., Literature Search: Z.E.B., S.A.B., B.G., D.A., Writing: Z.E.B., S.A.B., D.A.

Conflict of Interest: No conflict of interest was declared by the authors.

Financial Disclosure: The authors declared that this study received no financial support.

\section{References}

1. Fernandes M, Munhoz RP, Carrilho PE, Arruda WO, Lorenzoni PJ, Scola RH, Werneck LC, Teive HA. Neurological disorders associated with glutamic acid decarboxylase antibodies: a Brazilian series. Arq Neuropsiquiatr 2012;70:657-661.

2. Honnorat J, Saiz A, Giometto B, Vincent A, Brieva L, de Andres C, Maestre J, Fabien N, Vighetto A, Casamitjana R, Thivolet C, Tavolato B, Antoine J, Trouillas P, Graus F. Cerebellar ataxia with anti-glutamic acid decarboxylase antibodies: study of 14 patients. Arch Neurol 2001;58:225-230.

3. Dalakas MC. The role of IVIg in the treatment of patients with stiff person syndrome and other neurological diseases associated with anti-GAD antibodies. J Neurol 2005;252:119-125.

4. Hadjivassiliou M, Boscolo S, Tongiorgi E, Grünewald RA, Sharrack B, Sanders DS, Woodroofe N, Davies-Jones GA. Cerebellar ataxia as a possible organ-specific autoimmune disease. Mov Disord 2008;23:1370-1377.

5. Mitoma H, Hadjivassiliou $\mathrm{M}$, Honnorat J. Guidelines for treatment of immune-mediated cerebellar ataxias. Cerebellum Ataxias 2015;2:14. 